\title{
Effects of Clipping on Burned and Unburned Creep- ing Bluestem
}

\author{
R.S. KALMBACHER, F.G.MARTIN, W.S. TERRY, D.H. HUNTER, AND L.D. WHITE
}

Abstract

Creeping bluestem (Schizachyrium stoloniferum), a major decreaser on Florida range, is adversely affected by graxing during the growing season after a winter burn. To compare the effect of defoliation of burned and unburned bluestem range, creeping bluestem was burned (or not burned) on 2 similar sites in February 1978 and 1979 and cut at $2,4,6,8$, and 10 months after burning. Once forage was initially cut, it was recut every 2 months. Dry matter (DM) yield, tiller density, total nonstructural carbohydrate (TNC), crude protein (CP), and in vitro organic matter digestibility (IVOMD) were determined. When forage was cut in April and recut every 2 months, average yield of creeping bluestem from unburned areas was $3,000 \mathrm{~kg} / \mathrm{ha}$ while that of burned was 2,350 $\mathrm{kg} / \mathrm{ha}$. Creeping bluestem yield from unburned areas declined linearly within both years as initial harvest was delayed, but delaying initial harvest date had no effect on forage yield from burned areas. Final tiller density was usually a cubic response in burned and unburned plants. Tiller density generally increased in plants cut 1 month after treatment, decreased in plants cut 2, 4,6 months after treatment, and increased in plants cut 10 and 12 months after treatment. Rhizomes of plants burned in February 1979, cut initially in April, and reharvested 4 times had 9.0\% TNC in March 1980, while unburned plants contained 10.2\% TNC. The response of CP and IVOMD in initial growth was quadratic or cubic with time of initial harvest because percentages were raised initially due to burning, then they dropped steadily to a low in August, after which they began to rise slightly. Protein content in unburned forage had either a negative linear response or had no significant regression with time of initial harvest. IVOMD in unburned forage exhibited a quadratic (1978) or a polynomial (1979) response with time of initial harvest where IVOMD increased or fluctuated in the growing season, usually decreasing in fall and winter. Analysis of regrowth data indicated that the response of crude protein and IVOMD was similar regardless of burn treatment. Quality of regrowth declined from June to August and steadily increased from August to December. Creeping bluestem would be weakened by grazing on 60-day intervals after a February burn. When prescribed burning of creeping bluestem range is carried out every 3 to 4 years, deferment of grazing until June after a February burn will allow grazing of relatively high quality forage and still maintain creeping bluestem stand vigor.

Proper timing of burning and grazing should assure the longevity and improve forage quality of creeping bluestem (Schizachyrium stoloniferum) (Yarlett 1963), one of the most important grasses on the flatwoods range. Many ranges have been depleted of creeping bluestem as a result of repeated burning and uncontrolled grazing and now are dominated with wiregrass (Aristida stricta) (Yarlett 1963). Burning is important on wiregrass range because both forage (Lewis and Hart 1972) and calf production (Kirk et al. 1974) are reduced with long-term protection from fire. However, management that is beneficial for wiregrass is detrimental for creeping bluestem. White and Terry (1979) indicated that burning

\footnotetext{
Authors are agronomist, Ona Agricultural Research Center, Ona, Fla. 33865 statistician and biologist, University of Florida, Gainesville 32611; environmental manager, Utah International, Inc., Fruitland, N. Mex. 87416; and extension range specialist, Texas Agricultural Extension Service, Uvalde 78801.

This article is Florida Agr. Exp. Sta. Pap. No. 4710.

Manuscript accepted 13 March 1985.
}

and grazing creeping bluestem resulted in reduced dry matter yield and leaf area, and there were fewer total tillers at the end of the growing season as compared with unburned areas.

Creeping bluestem is relatively high in dry matter yield (Kalmbacher et al. 1981) and it is palatable and dominant in cattle diets (Kalmbacher et al. 1984). Crude protein and in vitro organic matter digestiblity (IVOMD) of creeping bluestem, like that of most flatwoods forages, is low (Kalmbacher et al. 1981, Kalmbacher 1983b). If pastures are winter burned and deferred during the following summer, as suggested by White and Terry (1979), forage quality will be poor as compared to that of forage grazed in the spring or summer. The purpose of this study was to determine when clipping (after burning) might reduce creeping bluestem stands and to measure the effects of burning on crude protein and digestibility in regrowth forage.

\section{Materials and Methods}

The experiment was conducted in 1978 and 1979 at the University of Florida's Ona Agricultural Research Center $\left(27^{\circ} 25^{\prime} \mathrm{N}\right.$, $81^{\circ} 55^{\prime} \mathrm{W}$ ). Different areas were used each year to eliminate the cumulative effect of burning on creeping bluestem. The soil on both areas was an unlimed, unfertilized Pomona fine sand (sandy, siliceous, hyperthermic Typic Haplaquod). Vegetation on the 2 areas was similar and almost entirely a natural stand of creeping bluestem with scattered Aristida spp., Dichanthelium spp, Andropogon spp., various forbs, and no palmetto (Serenoa repens) or other shrubs. The creeping bluestem was rank, well established, and had not been burned, grazed, or disturbed for 8 years.

The study plots were permanent $1-\mathrm{m}^{2}$ quadrats ( 20 in 1978, 28 in 1979), and they were selected to assure uniformity of creeping bluestem. Live bluestem tillers in each quadrat were counted in February prior to treatment. An additional 20 quadrats $0.25 \mathrm{~m}^{2}$ were harvested ( 1 to $2-\mathrm{cm}$ stubble) and separated into dead and living components for dry matter yield determination so that yield of green herbage that was burned could be subtracted from initial harvests of unburned forage. Initial harvest values would then represent dry matter accumulated between the burn and initial harvest.

One half of the experiment was back-fired (25 Feb. 1978, 9 Feb. 1979), and the other half was not burned. After $2,4,6,8$, and 10 (and 1 and 12 months in 1979) months following the burn, tillers were re-counted, and all forage in the appropriate $1-\mathrm{m}^{2}$ area was harvested $7 \mathrm{~cm}$ above the soil surface. Once quadrats were harvested initially, they were reharvested on succeeding 2-month intervals. Quadrats harvested initially 2 months after the February burn were reharvested 4 times, plots harvested initially 4 months after burning were reharvested 3 times, etc.

Harvested forage from each quadrat was analyzed for dry matter content, crude protein $(C P=N \times 6.25)$ (Gallaher et al. 1977, Issac and Johnson 1976), and in vitro organic matter digestibility (IVOMD) (Moore et al. 1972). Total nonstructural carbohydrate (TNC) in rhizomes of creeping bluestem were analyzed in 1979 (Smith 1981) with the following modifications: (1) amylo-glucosidase and invertase were used instead of takadiastase enzyme, and (2) the filtrate was not treated after enzyme hydrolysis with lead acetate and potassium oxalate. The extract was analyzed for reducing sugars using the colorimetric test of Nelson (1944) and Somogyi 
Equotion for total yield $(\mathrm{kg} / \mathrm{ha})$ No Burn: $3610-220 T R^{2}=0.98$

Burn: no sign. regression

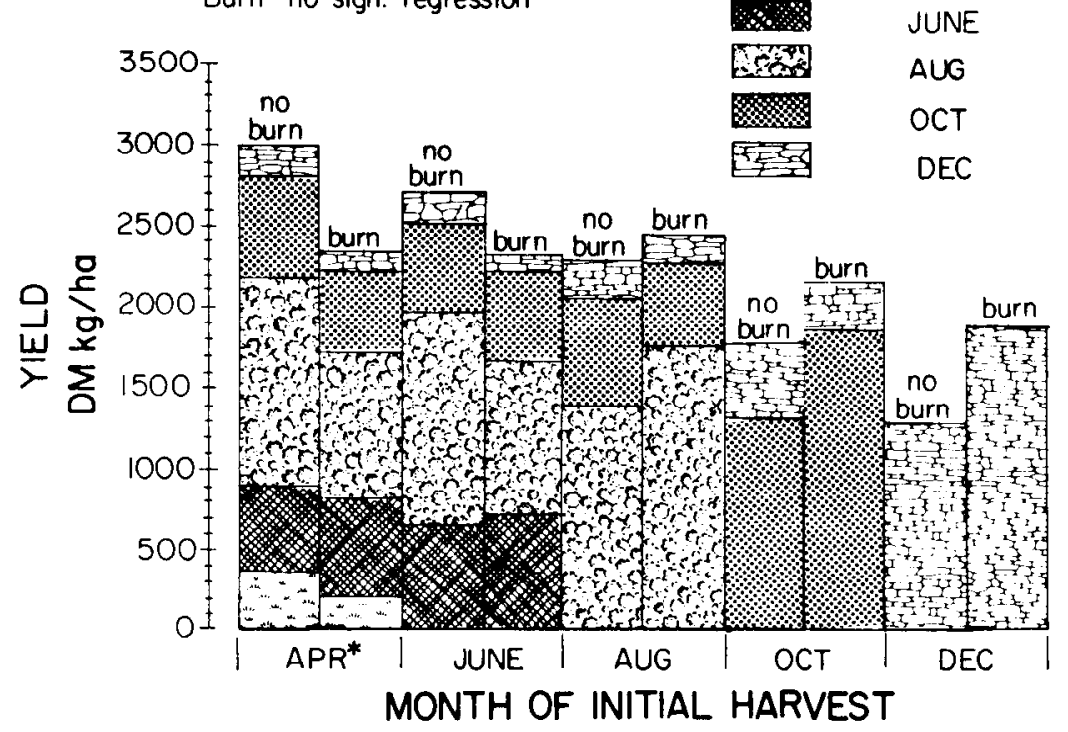

Fig. 1. Effect of burning and time ( $T$ is months since burning) of initial clipping on total dry matter yield of creeping bluestem. When forages were cut initially they were recut every subsequent 2 months. Average of 1978 and 1979. Ona. Fla.

* difference between burn and not burned forage significant $(P<0.05)$.

(1952) with glucose as the standard.

The basic design of this experiment was a split-plot with burning (yes, no) as the unreplicated whole plot treatment and times of harvesting after burning as subplot treatments. Whole plot areas were approximately $50 \times 50 \mathrm{~m}$ each, and the subplots, which were $1-\mathrm{m}^{2}$ selected quadrats, were scattered within burned and unburned whole plots. Subplot treatments were replicated 4 times and assigned at random to the $1-\mathrm{m}^{2}$ quadrats within each main plot. Data were pooled from the burned and unburned whole plots and analyzed as a series of experiments (Cochran and Cox 1957). The interaction was used to provide qualitative estimates of variation in response between burned and unburned areas. Yields were analyzed over years while other variables were analyzed within years.

Analysis of covariance was used to analyze final tiller count with the covariate being the initial count. Both burned and unburned means were adjusted to the same initial count of 184.4 in 1978 and 166.3 in 1979 to facilitate comparisons. Polynomial equations in time (month after burn) were fitted to the adjusted means with the degree of the equation based on the results of the covariance analysis.

Yield, first harvest crude protein, and IVOMD were analyzed using standard analysis of variance techniques with polynomial regression equations estimated to explain any significant effect of time. Analysis of crude protein and IVOMD at month of regrowth harvest required a direct application of the method of least squares because of the unbalanced structure of the data.

Rhizomes for TNC analyses came from separate $6 \times 6-\mathrm{m}$ plots in burned and unburned whole plots. These TNC sample areas were harvested at the same times as their respective subplots (viz., 2, 4, 5, etc., months after burn). The $6 \times 6-\mathrm{m}$ plots were not replicated in the whole plots, but a dozen rhizomes were composited from within each sample area, and 4 subsamples were analyzed in the laboratory.

\section{Results and Disucssion}

\section{Dry Matter Yield}

A burn $\times$ time of initial harvest interaction was evident for dry matter yield (Fig. 1). As initial harvest was delayed, the 2-year average total dry matter yield of forage from the unburned areas decreased linearly. In contrast, date of initial harvest did not influence DM yield of burned areas.

Initial harvest yields indicated that there was little dry matter accumulation before June or after August (Fig. 1). The main forage production period for creeping bluestem is June to August (Kalmbacher et al. 1981), and it was production during this period that was apparently reduced by burning and harvesting during April and June. Forage production from June to August in unburned plots harvested initially in April was $1,300 \mathrm{~kg} /$ ha vs 900 $\mathrm{kg} / \mathrm{ha}$ in burned plots.

\section{Tiller Number}

Analysis of tiller density indicated that burning treatments and time of initial clipping treatments interacted in 1978 (Table 1). The interaction was apparently due to the dramatic increase in tillers on the burned area 10 months after burning, when there were 254 tillers $/ \mathrm{m}^{2}$ in unburned plots compared to 157 tillers $/ \mathrm{m}^{2}$ in burned plots. The reasons for this response are unknown. Temperature and rain were near the 37-year average for November and December 1979, yet all 4 replications were consistently greater $(40 \%)$ in tiller number at the tenth month as compared with the eighth month. Time of clipping had a linear response on tiller density in burned plots and a cubic response on unburned plots. Time had a significant $(P<0.01)$ effect on tiller density of both burned and unburned treatments in 1979, but there was no significant interaction. Cubic equations described both burning treatments in 1979, but it is felt that such relationships are not biologically meaningful. This is especially true in 1978 burn treatment because the value 254 tillers $/ \mathrm{m}^{2}$ is unrealistic and not admissible for determining the relationship. The importance of these data is that they indicate that time of initial harvest did not significantly reduce tiller density. Although no mean separations were applicable, average number of tillers $/ \mathrm{m}^{2}$ in the burned and no burned treatments were 130 and 138 in 1978 , respectively, and 136 and 158 , in 1979.

This study and previous work by Kalmbacher et al. (1981), in which unburned creeping bluestem was cut at a $20-\mathrm{cm}$ stubble throughout the year for 3 continuous years without significant 
Table 1. Effect of burning and time of clipping on final tiller density of creeping bluestem in 1978 and 1979 . When bluestem was cut initially it was recut every subsequent 2 months. Ona, Florida.

\begin{tabular}{|c|c|c|c|c|c|c|c|c|c|c|}
\hline \multirow[b]{2}{*}{ Year } & \multirow[b]{2}{*}{ Burn } & \multicolumn{7}{|c|}{ Months of Cutting after Burn } & \multirow[b]{2}{*}{ Equation $\uparrow$} & \multirow[b]{2}{*}{$R^{2}$} \\
\hline & & 1 & 2 & 4 & 6 & 8 & 10 & 12 & & \\
\hline 1978 & $\begin{array}{l}\text { No } \\
\text { Yes }\end{array}$ & - & $\begin{array}{l}119 \\
107\end{array}$ & $\begin{array}{l}112 \\
109\end{array}$ & $\begin{array}{c}\mathrm{Jp} / \mathrm{m} \\
129 \\
107\end{array}$ & $\begin{array}{l}133 \\
109\end{array}$ & $\begin{array}{l}157 \\
254\end{array}$ & - & $\begin{array}{l}100.5+4.9 \mathrm{~T} \\
\text { cubic relationship } \ddagger\end{array}$ & $\begin{array}{l}92.7 \\
98.7\end{array}$ \\
\hline 1979 & $\begin{array}{l}\text { No } \\
\text { Yes }\end{array}$ & $\begin{array}{l}213 \\
217\end{array}$ & $\begin{array}{l}121 \\
130\end{array}$ & $\begin{array}{l}123 \\
138\end{array}$ & $\begin{array}{l}132 \\
147\end{array}$ & $\begin{array}{l}105 \\
148\end{array}$ & $\begin{array}{l}128 \\
167\end{array}$ & $\begin{array}{l}128 \\
152\end{array}$ & $\begin{array}{l}\text { cubic relationship } \ddagger \\
\text { cubic relationship }\end{array}$ & $\begin{array}{l}67.7 \\
68.6\end{array}$ \\
\hline
\end{tabular}

+T is time in months.

$\$ 1978$ burn, tiller no. $/ \mathrm{m}^{2}=13.53+98.60 \mathrm{~T}-22.67 \mathrm{~T}^{2}+1.55 \mathrm{~T}^{3}$

1979 no burn, tiller no $/ \mathrm{m}^{2}=243.80-59.31 \mathrm{~T}+8.23 \mathrm{~T}^{2}-0.84 \mathrm{~T}^{3}$

1979 burn, tiller no. $/ \mathrm{m}^{2}=257.72-68.75 \mathrm{~T}+11.11 \mathrm{~T}^{2}-0.51 \mathrm{~T}^{3}$

decline in dry matter yield, have demonstrated creeping bluestem's persistence when clipped in the vegetative stage. Results differed from that reported by White and Terry (1979), who observed a significant decline in tiller density when burned plants were grazed during the growing season after a winter burn. The work of White and Terry (1979) demonstrated the susceptibility of creeping bluestem to stand loss when defoliated between transition and flowering stages. This difference may be the result of differences associated with morphology of creeping bluestem. In their study creeping bluestem (also at Ona, Florida) flowered, whereas the plants at our study did not flower after burning. It seems likely that the conditions of the burn and/or physiological condition of the creeping bluestem plant determine if the plant flowers.

Removal of the apical meristem after its transition from vegetative to reproductive growth and subsequent elevation (jointing stage) has been shown to have detrimental effects on grasses (Branson 1958, Booysen et al. 1963). A decline in TNC is associated with flowering (White 1973). Carbohydrate depletion in a single season could be responsible for the reduction in tillers and yield experience by White and Terry (1979). Burning did not affect final storage of carbohydrate on unclipped big bluestem (Andropogon gerardi), but reduced reserves on clipped plots (Owensby et al. 1970).

\section{Total Nonstructural Carbohydrate}

The content of TNC in the rhizomes of burned plants was $9.0 \%$ as compared with $10.2 \%$ in unburned plants in March 1980. These plants had been burned in February 1979, harvested initially in April 1979 and reharvested 4 times. Rhizomes from similarly treated burned plants, which were not cut until 1 year after burning, were $8.8 \%$ TNC in March 1980, while unburned plants were $10.1 \%$. Earlier studies (Kalmbacher 1983a) had shown that TNC content of February burned creeping bluestem plants declined to percentages lower than that of unburned plants, but the unburned plants recovered within 60 days and remained at a higher TNC level than unburned plants until October.

Although tests of significance cannot be used because the carbohydrate sample-blocks were not replicated, the TNC contents of these rhizomes do show a small disparity between burned and unburned creeping bluestem. Burning followed by clipping every 60 days for a single year did not appear to have an effect on TNC content when compared to that of unclipped, burned plants.

\section{Crude Protein and IVOMD Initial Harvest}

Crude protein and IVOMD of initial harvest creeping bluestem exhibited a burning treatment $X$ month of initial harvest (Figs. 2 and 3 ) interaction in both years. Crude protein in forage from the burn treatment was 8 to $10 \% 1$ to 2 months after but declined steadily to about $4 \%$ in June. Protein from the burn treatment was at least a cubic response, but was either linear or without a significant regression in the unburned treatment. Forage from the unburned treatment remained about 3 to $4 \%$ crude protein year-

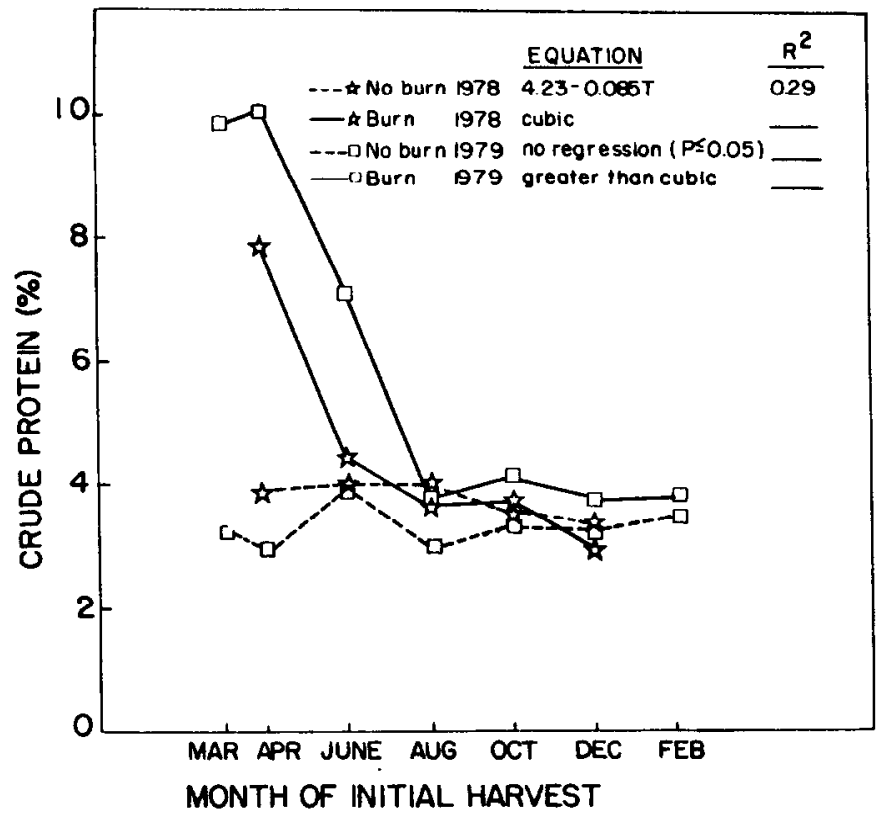

Fig. 2. Effect of burning and time ( $T$ is months since burning) of initial harvest on crude protein content of creeping bluestem. Ona, Florida. 1978 and 1979.

long. IVOMD in forage from the burn treatment was similar in trend to crude protein because IVOMD declined steadily from 54 to $62 \% 1$ to 2 months after burning to 22 to $31 \%$ in December. Regression equations describing IVOMD in burned creeping bluestem were quadratic. Similar equations described IVOMD in unburned bluestem, but digestibility of unburned bluestem was initially lower in the early spring, increased in the summer with new growth, then declined in fall.

These data indicated that in order for a rancher to take advantage of the improved crude protein and digestibility as a result of burning, he must put livestock on the burned range before August. June to August are very hot-humid months, and south Florida's soils are usually saturated by rain. These conditions apparently have an adverse effect on creeping bluestem quality.

\section{Regrowth Harvest}

Crude protein and IVOMD of regrowth was primarily affected by month of reharvest (Figs. 4 and 5). Both crude protein and IVOMD tended to be greater in June, October, and December as compared with August regrowth.

Analysis of 1978 regrowth data indicated regrowth harvest affected crude protein regardless of burn treatment, while IVOMD 


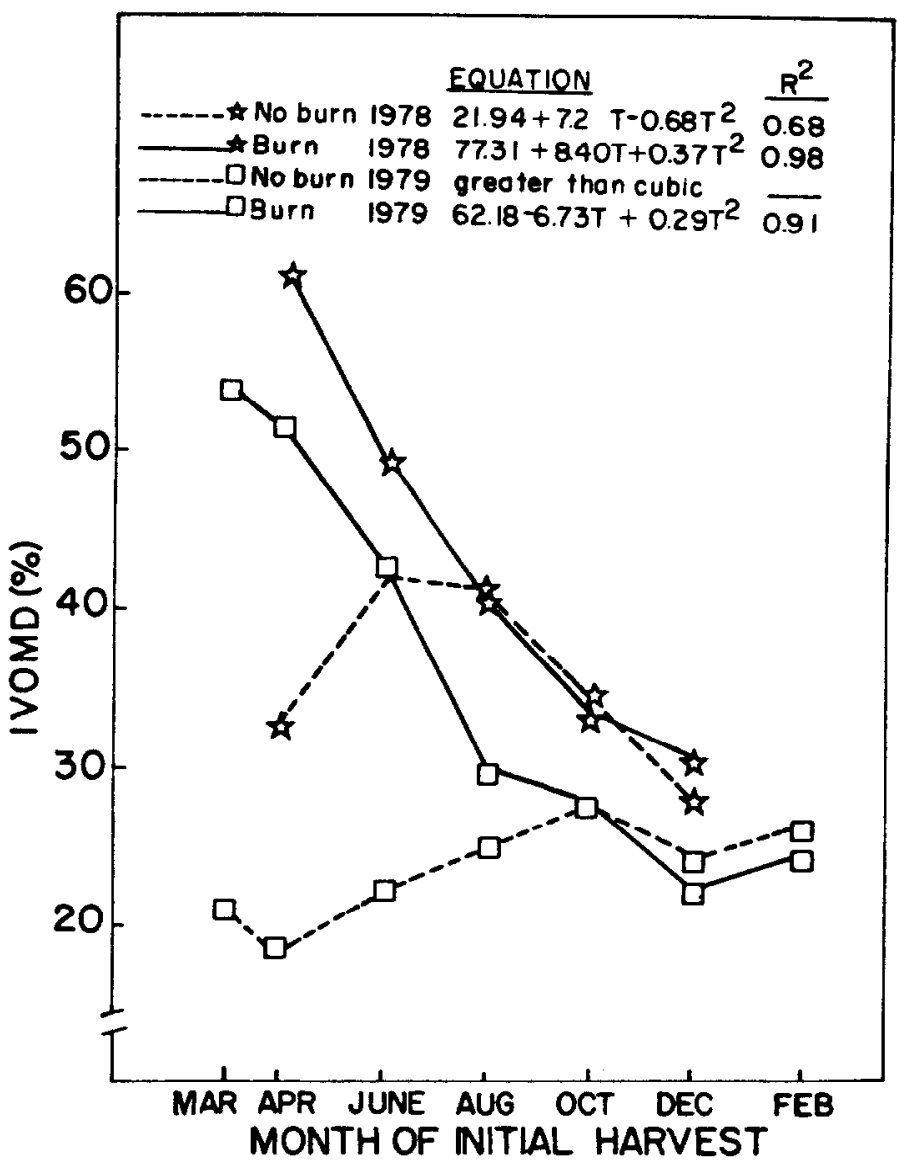

Fig. 3. Effect of burning and time ( $T$ is months since burning) of initial harvest on IVOMD content of creeping bluestem. Ona, Florida. 1978 and 1979.

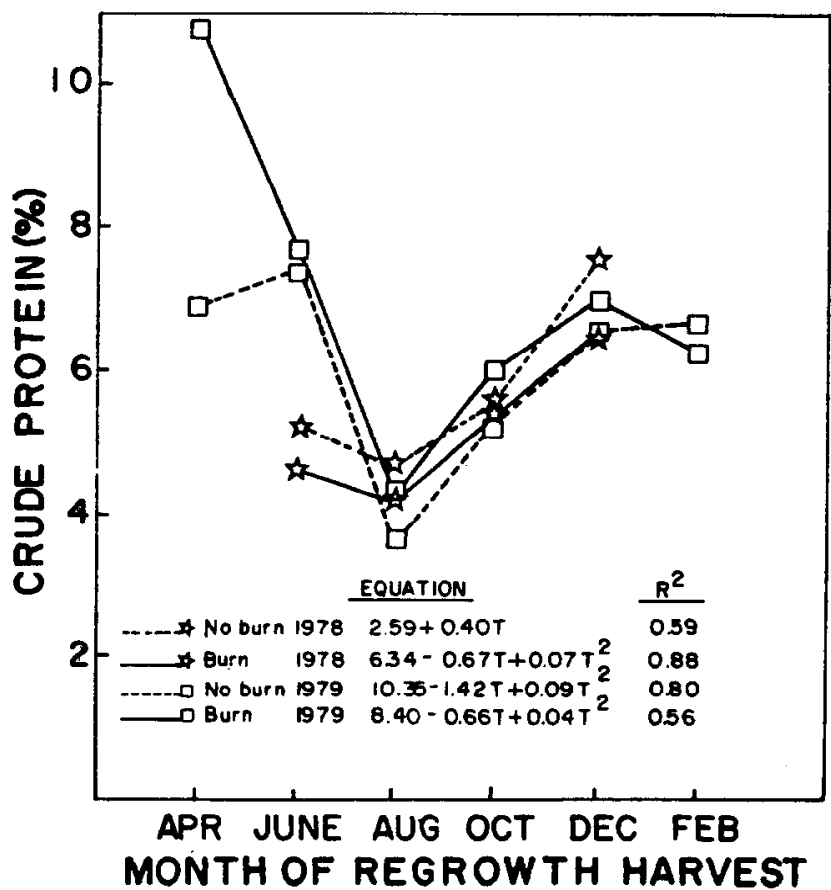

Fig. 4. Effect of burning and time (Tis months since burning) of regrowth harvest on crude protein content of creeping bluestem. Ona, Florida, 1978 and 1979.

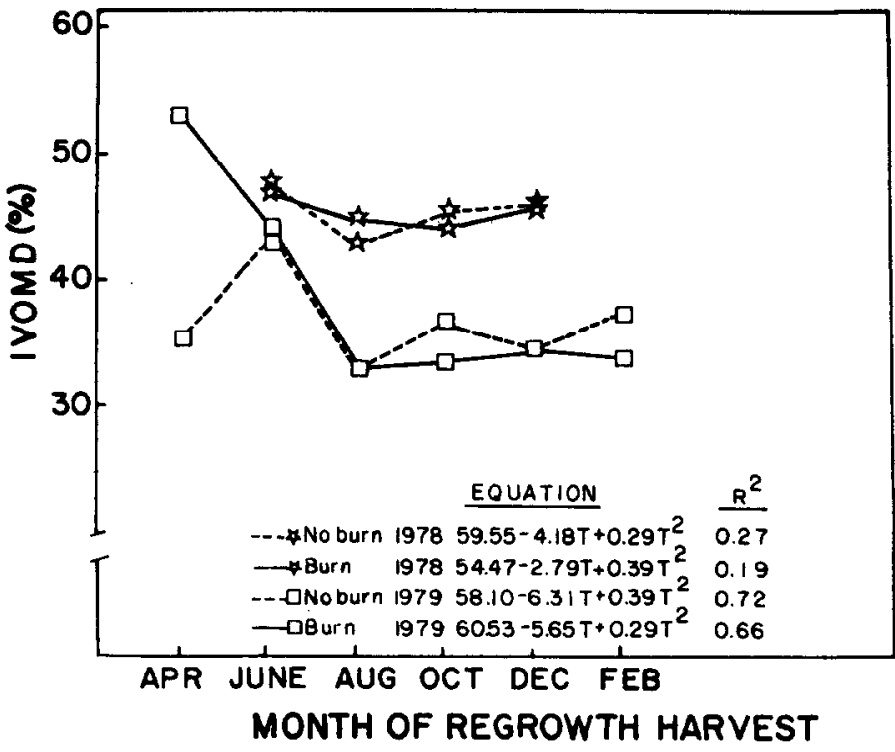

Fig. 5. Effect of burning and time (T is months since burning) of regrowth harvest on IVOMD of creeping bluestem. Ona, Florida. 1978 and 1979.

was affected only if bluestem was not burned. Regression equations were fitted to these means, and except for 1978 crude protein in unburned plants, the relationships were quadratic. The relationship in 1978 for IVOMD of regrowth from burned plants was significant only at the $10 \%$ level. All responses for protein and IVOMD in both burn treatments were quadratic.

It is important to note the effect that time of regrowth harvest had on crude protein and IVOMD. Both protein and IVOMD dropped in August, then increased in the fall and winter months. Regrowth from cooler months has been shown to have higher crude protein and IVOMD \% (Kalmbacher et al. 1981).

\section{Conclusion}

Improved crude protein and digestibility of regrowth could be realized if forage was burned in February, grazed in June, then regrazed in October or December. Such a grazing scheme would take advantage of higher quality in initial growth forage due to burning, allow for regrowth when creeping bluestem growth is great (June to August), and provide good quality regrowth for winter. This does not imply that creeping bluestem should be burned annually, but when part of a normal 3 to 5 year prescribed burning plan, it would allow for good quality forage without stand loss.

\section{Literature Cited}

Booysen, P. de V., N.M. Taintor, and F.D. Scott. 1963. Shoot apex development in grasses and its importance in grassland management. Herbage Abstr. 33:209-213.

Branson, F.A. 1953. Two new factors affecting resistance of grasses to grazing. J. Range Manage. 6:165-171.

Cochran, W.G., and G.M. Cox. 1957. Experimental designs. John Wiley and Sons, Inc. London.

Gallaher, R.N., C.O. Weldon, and F.C. Boswell. 1976. A semi-automated procedure for total nitrogen in plant and soil samples. Soil Sci. Soc. Amer. Proc. 40:887-889.

Issac, R.A., and W.C. Johnson. 1976. Determination of total nitrogen in plant tissues using a block digestor. J. Ass. Off. Anal. Chem. 69:98-101.

Kalmbacher, R.S. 1983a. Total non-structural carbohydrates in burned and unburned creeping bluestem roots, rhizomes and lower stems. Proc. Soil and Crop Sci. Soc. Fla. 42:142-145. 
Kalmbacher, R.S. 1983b. Distribution of dry matter and chemical constituents among parts of four Florida native grasses. J. Range Manage. 36:298-301.

Kalmbacher, R.S., Long, M.K. Johnson, and F.G. Martin. 1984. Botanical composition of diets of esophageal fistulated steers grazing south Florida rangeland. J. Range Manage. 37:334-340.

Kalmbacher, R.S., F.G. Martin, and J.M.S. Andrade. 1981. Yield and quality of creeping bluestem as affected by time of cutting. J. Range Manage. 34:471-474.

Kirk, W.G., E.M. Hodges, F.M. Peacock, L.L. Yarlett, and F.G. Martin. 1974. Production of cow-calf herds: effects of burning native range and supplemental feeding. J. Range Manage. 27:136-139.

Lewis, C.E., and R.H. Hart. 1972. Some herbage responses to fire on pine-wiregrass range. J. Range Manage. 25:209-213.

Moore, J.E., G.O. Mott, D.G. Dunham, and R.W. Omer. 1972. Forage capacity in vitro DM digestion procedure. J. Anim. Sci. 35:232. Abstr. No. 261 .
Nelson, N. 1944. A photometric adaptation for the Somogyi method for the determination of glucose. J. Biol. Chem. 153:375-380.

Owensby, C.E., G.M. Paulsen, and J.D. McKendrick. 1970. Effect of burning and clipping on big bluestem reserve carbohydrates. J. Range Manage. 23:358-362.

Smith, D. 1981. Removing and analyzing total non-structural carbohydrates from plant tissue. Wis. Agr. Exp. Sta. Res. Rep. R2107.

Somogyi, M. 1952. Notes on sugar determination. J. Biol. Chem. 195:19-23.

White, L.M. 1973. Carbohydrate reserves in grasses: a review. J. Range Manage. 26:13-18.

White, L.D., and W.S. Terry. 1979. Creeping bluestem response to prescribed burning and grazing in south Florida. J. Range Manage. 32:369-371.

Yarlett, L.L. 1963. Some important and associated native grasses on central and south Florida ranges. J. Range Manage. 16:25-27. 